\title{
Surface Plasmon Resonance as a Characterization Tool for Lipid Nanoparticles Used in Drug Delivery
}

\author{
Cecilia Yamil Chain *, María Antonieta Daza Millone*, José Sebastián Cisneros, \\ Eduardo Alejandro Ramirez and María Elena Vela
}

Instituto de Investigaciones Fisicoquímicas Teóricas y Aplicadas (INIFTA- Universidad Nacional de La Plata (UNLP)- Consejo Nacional de Investigaciones Científicas y Técnicas (CONICET)), La Plata, Argentina

The development of drug carriers based in lipid nanoparticles (LNPS) aims toward the synthesis of non-toxic multifunctional nanovehicles that can bypass the immune system and allow specific site targeting, controlled release and complete degradation of the carrier components. Among label free techniques, Surface Plasmon Resonance (SPR) biosensing is a versatile tool to study LNPs in the field of nanotherapeutics research. SPR, widely used for the analysis of molecular interactions, is based on the immobilization of one of the interacting partners to the sensor surface, which can

OPEN ACCESS

Edited by:

Guillermo Raul Castro, National University of La

Plata, Argentina

Reviewed by:

Aihua Liu,

Qingdao University, China Wei-Lung Tseng,

National Sun Yat-sen

University, Taiwan

*Correspondence:

Cecilia Yamil Chain

yamil@inifta.unlp.edu.ar María Antonieta Daza Millone dazamillone@inifta.un/p.edu.ar

Specialty section:

This article was submitted to

Analytical Chemistry,

a section of the journal

Frontiers in Chemistry

Received: 18 September 2020 Accepted: 04 December 2020 Published: 07 January 2021

Citation:

Chain CY, Daza Millone MA Cisneros JS, Ramirez EA and Vela ME (2021) Surface Plasmon Resonance as a Characterization Tool for Lipid Nanoparticles Used in Drug Delivery.

Front. Chem. 8:605307. doi: 10.3389/fchem.2020.605307 be easily achieved in the case of LNPs by hydrophobic attachment onto commercial lipid- capture sensor chips. In the last years SPR technology has emerged as an interesting strategy for studying molecular aspects of drug delivery that determines the efficacy of the nanotherapeutical such as LNPs' interactions with biological targets, with serum proteins and with tumor extracelullar matrix. Moreover, SPR has contributed to the obtention and characterization of LNPs, gathering information about the interplay between components of the formulations, their response to organic molecules and, more recently, the quantification and molecular characterization of exosomes. By the combination of available sensor platforms, assay quickness and straight forward platform adaptation for new carrier systems, SPR is becoming a high throughput technique for LNPs' characterization and analysis.

Keywords: lipid nanoparticles, drug carriers, Surface Plasmon Resonance, molecular target, protein corona

\section{INTRODUCTION}

Drug delivery has been improved over the years with continuous effort to develop new and more efficient carriers. Nowadays, drug carrier design points toward a non-toxic multifunctional nanoparticle (NP) that eludes the immune system and allows site-specific targeting, on-demand drug release and complete degradation of the carrier components (Choi and Han, 2018; Li et al., 2019; Yan et al., 2019; Zhao et al., 2019; Yeh et al., 2020).

Lipid-based nanoparticles (LNPs) bear the advantages for in vivo applications of being nontoxic and biodegradable (Puri et al., 2009) and they have probed their usefulness as vehicles for dermal, transdermal, mucosal, parenteral and ocular drug administration routes (Allen and Cullis, 2013; Desfrançois et al., 2018). Among them, phospholipid vesicles or "liposomes" were the first and so far most successful form of nanocarriers, with the larger number of approved formulations (Bozzuto and Molinari, 2015; Pattni et al., 2015; Bunker et al., 2016; Zylberberg and Matosevic, 2016; Li et al., 2019). Liposomes can be modified with a "stealth sheath," e.g., with poly- ethylene glycol (PEG), to avoid the complement activation of the immune system. Another strategy to evade 
the immune system is to utilize natural vesicles such as exosomes (György et al., 2015; Ha et al., 2016; Wiklander et al., 2019). On the other hand, immunogenic properties can be exploited for targeting in virus-like particles (VLPs) that display effective cell entry properties due to their viral origin (Zdanowicz and Chroboczek, 2016; Rohovie et al., 2017). Nevertheless, all these vesicles lack of long-term storage stability and, if taken orally, they suffer a rapid degradation by stomach $\mathrm{pH}$, bile salts or intestinal enzymes (Selvamuthukumar and Velmurugan, 2012). These difficulties and the need of compatible largescale manufacturing lead to the development of solid lipid nanoparticles (SLNs) and, more recently, nanostructured lipid carriers (NLCs) (Naseri et al., 2015; Oner et al., 2020). NLCs incorporate small amounts of liquid lipids in the formulation diminishing matrix crystallization, increasing drug loading and preventing drug expulsion during storage and they have proved to be cytocompatible (Rodenak-Kladniew et al., 2019; Bueloni et al., 2020) and effective for different delivery routes.

The adequate characterization of LNPs is crucial to obtain drug vehicles and to understand their behavior in biological systems. The characterization methods should focused on the LNP's parameters that determine their usefulness in nanotherapeutics: particle size and zeta potential, drug loading and drug release, stability and biomolecular interactions, among others (Mehnert and Mäder, 2012). Most of the conventional methods to study biomolecular interactions require labeling, such as ELISA, fluorescence techniques or MicroScale Thermophoresis (MST) (Jerabek-Willemsen et al., 2014). Among label-free techniques, binding affinity can be assessed by Isothermal Titration Calorimetry (ITC) (Duff et al., 2011) or Biolayer Interferometry (BLI) (Weeramange et al., 2020) but, as they lack from dynamic flow conditions, kinetic parameters cannot be determined. Surface Plasmon Resonance (SPR) spectroscopy is a label free optical technique capable of realtime measuring through changes in the refractive index (RI) in the vicinity of a metal surface. To do so, one binding partner (ligand) is immobilized on a sensor chip while the free counterpart (analyte) from a sample solution is injected through a microfluidic setup (Figure 1A). Although similar information is provided by the quartz crystal microbalance (QCM), in this case the obtained data depends both on the analyte binding and on the water displacements that can occur due to the interaction, affecting the obtained results (Tonda-Turo et al., 2018).

The aim of this review is to outline the state of the art in SPR sensing of LNPs, describing its usefulness and challenges in the framework of drug delivery research.

\section{SURFACE PLASMON RESONANCE}

\subsection{Principle}

In order to achieve the SPR phenomenon, a material that exhibits a free electron behavior is required, as it occurs with the conduction band electrons in metals (Maier, 2007). Plasmons are quantized waves of the collective movement of electrons resulting from the interaction with photons from a $p$-polarized light source. The propagation of plasmons, now surface plasmonpolaritons (SPPs), produces alternating positive and negative regions that in contact with a lower RI medium result in a confined evanescent field, that decays exponentially in the perpendicular direction at both sides of the interface (Figure 1B). Small changes in RI within the evanescent field will greatly alter the propagation properties of SPPs, reason why this phenomenon drew attention as an analytical technique.

The resonant condition, where the largest number of photons can excite SPPs, will be reached when the light wavevector in the propagation direction $\left[\mathrm{k}_{\mathrm{o}(\mathrm{x})}\right]$ matches the wavevector of the SPPs $\left(\mathrm{k}_{\mathrm{SPP}}\right)$. There are different strategies to achieve this matching, the most widely employed method in SPR instruments is the Kretschmann configuration (Figure 1B) where SPP excitation is attained through total internal reflection (TIR) (Schasfoort, 2017). Depending on the incident angle $\left(\Theta_{\mathrm{i}}\right)$, the $\mathrm{k}_{\mathrm{o}(\mathrm{x})}$ light component is absorbed by SPPs, resulting in a drop of reflectivity (R) (Figure 1C). At a given RI in the medium, $\Theta_{S P R}$ allows the maximum light absorption by SPPs and the minimum reflected light. As RI changes, i.e., by molecules in a solution, $\mathrm{k}_{\mathrm{SPP}}$ is modified and a different $\Theta_{S P R}$ is required to fulfill the new resonance condition. SPR measurements are usually carried out at a fixed $\Theta_{\mathrm{i}}$ and changes expressed as SPR response (either $\Delta \mathrm{R}$ or $\Delta \Theta)$ are registered as a function of time (Figure 1D), yielding curves known as sensorgrams.

\subsection{Measurement Data and Analysis}

SPR sensors chips are usually gold coated glass plates. The optimal gold layer thickness of $\sim 50 \mathrm{~nm}$ allows to achieve high sensitivity (Fontana, 2006) and the glass side is coupled to a prism through a RI matching fluid or polymer (Figure 1B). A flow cell is placed upon the gold surface enclosing one or more flow channels. The microfluidic SPR setup allows to infuse a running buffer and a sequential injection of small volume $(50-1,000 \mu \mathrm{L})$ sample solutions that will interact with the sensor platform (Figure 1A). The adequate choice of the flow rate is critical to avoid mass transport limitations or shear stress effects.

Platform design should be optimized to prevent steric hindrance that can affect binding events. Depending on the application, the gold layer needs to be modified (section 3) and a biocompatible organic layer (thiol self-assembled monolayerSAM- or polymer), eventually exhibiting anchor points for immobilization, is placed onto the surface (Gedig, 2017). Ligand immobilization can take place either ex situ or in situ, in the latter case the immobilized amount can be quantified (Figure 1D; Albers and Vikholm-Lundin, 2011). For immobilization by covalent attachment, crosslinker reagents are injected in the first place to activate the surface (Figure 1D, step I) and the ligand solution is subsequently passed over for a time period that allows conjugation (Figure 1D, step II). On the other side, a ligand solution can be directly injected without previous activation (Figure 1D, step II) if immobilization is based on physical attachment, i.e., by hydrogen bonding or hydrophobic forces. Finally, a washing procedure (Figure 1D, step III) is employed to either remove weakly bound material and/or deactivate the reactive functional groups generated in step I.

Once the surface is ready, a solution containing the analyte is injected allowing association (Figure 1D, step IV) and registering 


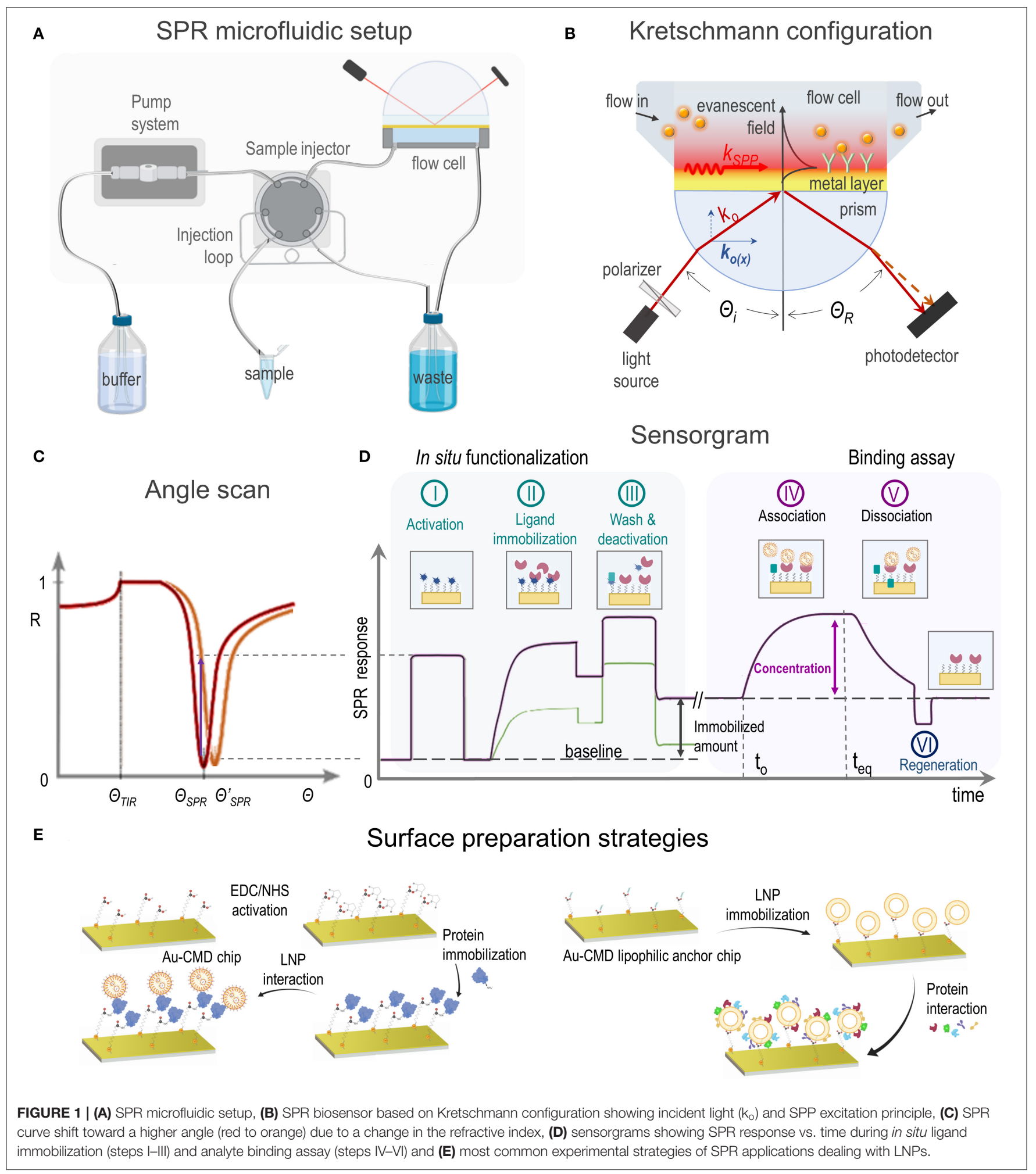

afterwards the dissociation (Figure 1D, step V). Before the next analyte assay the surface must be regenerated (Figure 1D, step VI) with the mildest solution that releases the analyte without damaging the immobilized ligand, i.e., diluted acids or bases, detergents, etc. As the amount of the SPR response at the steady state $\left(\mathrm{t}_{\mathrm{eq}}\right)$ is related to the analyte concentration and possible matrix interferents, control experiments must be carefully designed in order to avoid data misinterpretation. 
Moreover, to minimize unspecific adsorption, a blocking step to reduce non-specific binding can also be included before the assay, e.g., by using a well-known protein solution.

\section{SURFACE PREPARATION STRATEGIES}

Since SPR studies of LNPs cover a great variety of applications, several immobilization methods have been utilized, mainly based on covalent immobilization or hydrophobic attachment of one of the interacting entities onto organic layer covered- gold sensor surfaces (Figure 1E). High affinity capture of ligands by a specific binding molecule and adsorption onto bare gold sensor chips have also been reported. In this section, a brief description of each immobilization method utilized in SPR studies of LNPs is presented. Reference papers corresponding to each subsection are listed in Table 1.

\subsection{Covalent Immobilization}

Among conjugation techniques to immobilize ligands to SPR surfaces, amide linkage (Hermanson, 2013) is the most employed strategy. Functional carboxylic groups are included in carboxymethyl dextran (CMD) or alginate coated commercial gold sensor chips or they can be obtained from bare sensor surfaces adequately covered with thiol SAMs (Table 1) based on the robust covalent bond that is established between $\mathrm{S}$ and $\mathrm{Au}$ (Vericat et al., 2010).

Although covalent coupling easily provides stable ligand immobilization to the sensor surface, it may modify active sites of proteins potentially affecting the analyte binding activity. In cases where the covalent immobilization of the ligand is unsuitable, capturing methods provide an alternative approach.

\subsection{Capturing Approaches}

Ligand immobilization based on high affinity streptavidin- biotin capture has also been reported in SPR studies dealing with LNPs. The surface preparation relies on the adequate attachment of streptavidin onto the sensor surface either through reaction with biotinylated alkanethiols (Meierhofer et al., 2010; Rupert et al., 2016), thiolated PEG (Im et al., 2017) or amide coupling (AlAhmady et al., 2014) and in the previous ligand's conjugation to biotin (Hermanson, 2013).

\subsection{Hydrophobic Attachment}

Immobilization of LNPs to SPR chips through hydrophobic interactions can be achieved by alkane chains incorporated in a polymeric coating, commercially referred to as "Au- lipid capture chips" or prepared by covering bare sensor chips with alkanethiol- SAMs (Table 1).

Most of SPR applications focused on surface attached LNPs are based on $\mathrm{Au}$ - lipid capture chips coated with CMD and functionalized with lipophilic substituents (Table 1), as these platforms yield the immobilization of "intact" LNPs (Figure 1E, right; Hodnik and Anderluh, 2013). On the other side sensor surfaces coated with alkanethiol groups, either obtained commercially (Tamiaki et al., 2006) or prepared by chemical modification of bare gold sensor chips (Malmsten, 1999; Efremova et al., 2000), have also been used to immobilize LNPs, with the limitation that NPs fuse to the surface generating a lipid monolayer onto the alkanethiol (Hodnik and Anderluh, 2013).

\subsection{Physical Adsorption}

Some SPR applications dealing with immobilized LNPs are based on simple physical attachment to SPR bare gold chips (Table 1) as some biomolecules show a strong spontaneous adsorption on gold surfaces (Hodnik and Anderluh, 2013). Nevertheless, the reorganization or uncontrolled exchange of the adsorbed entities to attain the most favorable thermodynamic state have been reported (Hodnik and Anderluh, 2013) which can result in unreliable assays.

\section{APPLICATIONS OF SPR-BASED BIOSENSORS IN THE STUDY OF LNPS}

SPR-based sensors are increasingly used to study a variety of LNPs such as liposomes, SLNs, NLCs, VLPs, exosomes and hybrid systems. In this section, examples of applications of SPR biosensing on drug LNPs' carriers in different areas of nanotherapeutics research are presented.

\subsection{LNPs' Interactions Involved in Drug Delivery}

\subsubsection{Interaction With Biological Targets}

One of the major challenges of nanotherapeutics is to selectively deliver NPs to the desired biological target. With this aim, NPs are functionalized with adequate targeting ligands resulting in decorated nanovehicles with enhanced capacity to direct selective binding. Analyses of interactions between LNPs and their biological molecular targets is a well-established research area of SPR, either by using isolated proteins, cell membranes or entire cells as target models (Table 1).

SPR experiments have been defining in the obtention of decorated liposomes with high affinity to amyloid- $\beta$ peptide (Gobbi et al., 2010; Mourtas et al., 2011; Gregori et al., 2017), contributing to the development of very promising vectors for the targeted delivery of potential new diagnostic and therapeutic molecules for Alzheimer's disease. SPR sensing based on surface immobilization of the target protein onto Au- CMD chips (Figure 1E, left) has also contributed to the elucidation of the interplay of decorated liposomes or SLNs and membrane proteins that are overexpressed in malignant tissues (Nielsen et al., 2002; Terada et al., 2007; Mizrahy et al., 2011; Shi et al., 2015a; Huang et al., 2019), in disease-supporting macrophages (Etzerodt et al., 2012; Rafique et al., 2019) or in T-cells involved in autoimmune diseases (Ding et al., 2015). Moreover, SPR studies based on immobilized liposomes (Figure 1E, right) have shed light on the complex mechanism for the interaction of lectins with glycoliposomes specially designed to target sugarbinding proteins (Tamiaki et al., 2006; Sandoval-Altamirano et al., 2017).

The interplay between LNPs and cell membranes or entire cells as biological targets have also been investigated by SPR (Table 1). In this regard, SPR has been applied to study the interaction of liposomes in solution and immobilized bacterial 
TABLE 1 | Summary of SPR studies on LNPs: research area, subject of study, immobilized ligand and analyte in solution, surface preparation strategy, and reference papers.

\begin{tabular}{|c|c|c|c|c|c|}
\hline $\begin{array}{l}\text { Lipid } \\
\text { nanoparticle }\end{array}$ & Research area & Subject of study & $\begin{array}{l}\text { Immobilized } \\
\text { ligand/analyte in } \\
\text { solution }\end{array}$ & $\begin{array}{l}\text { Sensor chip and surface } \\
\text { immobilization chemistry }\end{array}$ & References \\
\hline \multirow[t]{20}{*}{ Liposomes } & $\begin{array}{l}\text { Molecular } \\
\text { interactions involved } \\
\text { in drug delivery }\end{array}$ & $\begin{array}{l}\text { Interaction with } \\
\text { biological targets } \\
(4.1 .1)\end{array}$ & Target protein/LNP & Au-CMD chip, amide coupling (3.1) & $\begin{array}{l}\text { Laukkanen et al., 1994; Nielsen } \\
\text { et al., 2002; Terada et al., 2007; } \\
\text { Mizrahy et al., 2011; Etzerodt et al., } \\
\text { 2012; Ding et al., 2015; Shi et al., } \\
\text { 2015a,b; Xiang et al., 2015; Gregori } \\
\text { et al., 2017; Huang et al., } 2019\end{array}$ \\
\hline & & & & Au-alginate chip, amide coupling (3.1) & $\begin{array}{l}\text { Gobbi et al., 2010; Mourtas et al., } \\
2011\end{array}$ \\
\hline & & & & Au chip, biotinylated thiol layer (3.2) & Viitala et al., 2012 \\
\hline & & & & $\begin{array}{l}\text { Au-CMD chip, amide coupling, } \\
\text { streptavidin (3.2) }\end{array}$ & Al-Ahmady et al., 2014 \\
\hline & & & LNP/target protein & Au 1-octadecanethiol SAM chip (3.3) & Tamiaki et al., 2006 \\
\hline & & & & $\begin{array}{l}\text { Au chip, 11-mercapto 1- undecanol SAM } \\
\text { (3.3) }\end{array}$ & Sandoval-Altamirano et al., 2017 \\
\hline & & & $\begin{array}{l}\text { Cell membrane } \\
\text { model/LNP }\end{array}$ & Au lipid- capture chip (3.3) & Cai et al., 2014; Wang et al., 2014 \\
\hline & & & Cell/LNP & Au-CMD chip, amide coupling (3.1) & Guo et al., 2014 \\
\hline & & & $\begin{array}{l}\text { Bacterial } \\
\text { biofilm/LNP }\end{array}$ & $\begin{array}{l}\text { Au chip, incubation with diluted bacterial } \\
\text { culture suspensions }\end{array}$ & Sugano et al., 2016 \\
\hline & & $\begin{array}{l}\text { Interaction with } \\
\text { serum proteins } \\
(4.1 .2)\end{array}$ & LNP/protein & Au lipid- capture chip (3.3) & $\begin{array}{l}\text { Akita et al., 2015; Shibata et al., } \\
\text { 2015; Kari et al., } 2017\end{array}$ \\
\hline & & & & Au chip, 1-octadecanethiol SAM (3.3) & $\begin{array}{l}\text { Malmsten, 1999; Efremova et al., } \\
2000\end{array}$ \\
\hline & & & & $\begin{array}{l}\text { Au chip, biotinylated thiol layer, } \\
\text { streptavidin (3.2) }\end{array}$ & Meierhofer et al., 2010 \\
\hline & & & Protein/LNP & Au-CMD chip, amide coupling (3.1) & Crielaard et al., 2011 \\
\hline & & & & Au-alginate chip, amide coupling (3.1) & Canovi et al., 2012 \\
\hline & & $\begin{array}{l}\text { Interaction with ECM } \\
\text { matrix (4.1.3) }\end{array}$ & Protein/ LNP & Au-CMD chip, amide coupling (3.1) & Wadajkar et al., 2019 \\
\hline & $\begin{array}{l}\text { Obtention and } \\
\text { characterization of } \\
\text { LNP's formulations }\end{array}$ & $\begin{array}{l}\text { Interaction between } \\
\text { components of the } \\
\text { formulations (4.2.1) }\end{array}$ & LNP/protein & Au lipid- capture chip (3.3) & $\begin{array}{l}\text { Rauscher et al., 2014; Skyttner } \\
\text { et al., } 2019\end{array}$ \\
\hline & & & LNP/PEG & Au chip (3.4) & Zhao et al., 2010 \\
\hline & & & Protein/LNP & Au-CMD chip, amide coupling (3.1) & Yatuv et al., 2009 \\
\hline & & $\begin{array}{l}\text { Response to organic } \\
\text { molecules (4.2.2) }\end{array}$ & LNP/detergent & Au-lipid capture chip (3.3) & Shibata et al., 2012 \\
\hline & & & LNP/glucose & Au chip (3.4) & Seong et al., 2003 \\
\hline \multirow[t]{3}{*}{ Hybrid NPs } & $\begin{array}{l}\text { Obtention and } \\
\text { characterization of } \\
\text { LNP's formulations }\end{array}$ & $\begin{array}{l}\text { Interaction between } \\
\text { components of the } \\
\text { formulations (4.2.1) }\end{array}$ & $\begin{array}{l}\text { Hybrid NP/targeting } \\
\text { peptide }\end{array}$ & Au lipid- capture chip (3.3) & Soman et al., 2008; Pan et al., 2011 \\
\hline & & & $\begin{array}{l}\text { Liposome/polymeric } \\
\text { NP }\end{array}$ & Au lipid- capture chip (3.3) & Gao et al., 2014 \\
\hline & $\begin{array}{l}\text { Molecular } \\
\text { interactions involved } \\
\text { in drug delivery }\end{array}$ & $\begin{array}{l}\text { Interaction with } \\
\text { biological targets } \\
(4.1 .1)\end{array}$ & Hybrid NP/cell & Au lipid. capture chip (3.3) & Soman et al., 2009 \\
\hline \multirow[t]{2}{*}{ Exosomes } & $\begin{array}{l}\text { Quantification and } \\
\text { molecular } \\
\text { characterization of } \\
\text { exosomes }\end{array}$ & $\begin{array}{l}\text { Quantification of } \\
\text { exosomes (4.3) }\end{array}$ & $\begin{array}{l}\text { Specific biotinylated } \\
\text { antibody/exosome }\end{array}$ & $\begin{array}{l}\text { Au chip, biotinylated thiol layer, } \\
\text { streptavidin (3.2) }\end{array}$ & Rupert et al., 2016 \\
\hline & & & $\begin{array}{l}\text { Streptavidin/ } \\
\text { biotinylated } \\
\text { exosome }\end{array}$ & Au chip, biotinylated thiol layer (3.2) & Rupert et al., 2014 \\
\hline
\end{tabular}


TABLE 1 | Continued

\begin{tabular}{|c|c|c|c|c|c|}
\hline $\begin{array}{l}\text { Lipid } \\
\text { nanoparticle }\end{array}$ & Research area & Subject of study & $\begin{array}{l}\text { Immobilized } \\
\text { ligand/analyte in } \\
\text { solution }\end{array}$ & $\begin{array}{l}\text { Sensor chip and surface } \\
\text { immobilization chemistry }\end{array}$ & References \\
\hline & & $\begin{array}{l}\text { Identification of } \\
\text { exosomal proteins } \\
\text { (4.3) }\end{array}$ & $\begin{array}{l}\text { Specific biotinylated } \\
\text { antibody/exosome }\end{array}$ & Au chip, thiolated PEG /streptavidin (3.2) & Im et al., 2017 \\
\hline \multirow[t]{2}{*}{ SLN } & $\begin{array}{l}\text { Molecular } \\
\text { interactions involved } \\
\text { in drug delivery }\end{array}$ & $\begin{array}{l}\text { Interaction with } \\
\text { biological targets } \\
(4.1 .1)\end{array}$ & Protein/LNP & Au-alginate chip, amide coupling (3.1) & Gobbi et al., 2010 \\
\hline & & $\begin{array}{l}\text { Interaction with } \\
\text { serum proteins } \\
(4.1 .2)\end{array}$ & Protein/LNP & $\begin{array}{l}\text { Au chip, 11-mercaptoundecanoic acid } \\
\text { SAM, amide coupling (3.1) }\end{array}$ & Di lanni et al., 2017 \\
\hline NLC & $\begin{array}{l}\text { Molecular } \\
\text { interactions involved } \\
\text { in drug delivery }\end{array}$ & $\begin{array}{l}\text { Interaction with } \\
\text { biological targets } \\
(4.1 .1)\end{array}$ & Protein/LNP & Au-CMD chip, amide coupling (3.1) & Rafique et al., 2019 \\
\hline VLP & $\begin{array}{l}\text { Molecular } \\
\text { interactions involved } \\
\text { in drug delivery }\end{array}$ & $\begin{array}{l}\text { Interaction with } \\
\text { biological targets } \\
(4.1 .1)\end{array}$ & $\begin{array}{l}\text { Cell membrane } \\
\text { model/LNP }\end{array}$ & Au lipid- capture chip (3.3) & Jedynak et al., 2018 \\
\hline
\end{tabular}

Parentheses indicate subsections where subjects of study and surface immobilization chemistries are described.

biofilms (Sugano et al., 2016) or tumoral cell lines (Guo et al., 2014), and a work describing the application of SPR to assess the interaction of immobilized hybrid NPs and eukaryotic cells in solution has been reported (Soman et al., 2009).

\subsubsection{Interaction With Serum Proteins}

It is well-known that the interaction of drug nanocarriers with serum proteins can alter the pharmacokinetics of the nanovehicles either affecting the cellular uptake or the clearance of the particles by the immune system (Pearson et al., 2014). SPR has been applied to study the interplay between NPs and isolated serum proteins in order to optimize LNP's formulation design (Table 1). SPR has contributed to study fibrinogen, human serum albumin and bovine pancreatic trypsin inhibitor adsorption onto both neutral and negatively charged PEG-decorated liposomes (Efremova et al., 2000). Interestingly, the observed reduction in protein adsorption as PEG densities in the nanovehicles increases agreed with theoretical predictions. These results suggest that SPR studies could contribute to establish the physical basis of the different interactions of LNPs with proteins and cells. Moreover, particular proteins of the NPs' corona were identified by means of SPR experiments on LNPs preincubated with serum (Canovi et al., 2012) and the real-time protein corona formation was followed on surface-immobilized NPs (Kari et al., 2017).

\subsubsection{Interaction With Tumor ECM}

Therapeutic efficacy of drug nanovehicles for cancer applications is significantly impaired by limited tumor tissue penetration due to a physical barrier formed by extracellular matrix (ECM) proteins. In this regard, SPR has been recently expanded as a method to examine the interfacial properties of liposomes, by analyzing their binding properties toward surface immobilized tumor ECM proteins as a surrogate for their ability to penetrate solid tumors (Wadajkar et al., 2019).

\subsection{Obtention and Characterization of LNPs' Formulations}

\subsubsection{Interaction Between Components of the LNPs'} Formulation

Stability, targeting specificity and drug release efficiency of nanosized drug carriers can be improved by nanovehicle's surface functionalization. In this sense, SPR has contributed to the optimization of LNP- based drug delivery systems by providing a rapid screening method to assess the interaction between LNP and potential binding molecules to be included in the final NP formulation (Table 1). Soman et al., by way of illustration, incorporated the peptide melittin in the outer lipid monolayer of perfluorocarbon (PFC) NPs and demonstrated the tight binding of this potential cancer chemotherapeutic with the nanocarriers from the SPR data (Soman et al., 2008).

\subsubsection{LNPs' Response to Organic Molecules}

LNPs can be easily captured on SPR chips by means of lipophilic anchors (Del Vecchio and Stahelin, 2016) as described in section 3.3 and the obtained sensor surfaces can be used to investigate the interplay of the immobilized nanovehicles and organic molecules in aqueous solutions (Seong et al., 2003; Shibata et al., 2015). For instance, Shibata et al. utilized SPR to study the interaction of different detergents (two bile salts and Triton X-100) and PEGylated liposomes that were immobilized to the surface of a lipid- capture chip (Shibata et al., 2012). The authors observed that the detergents were either bound to or partitioned into lipid bilayers and they subsequently solubilized and dissociated from the chip. These results suggest that SPR can provide an automatized method to simply address the solubilization and interaction of detergents with LNPs. 


\subsection{Quantification and Molecular Characterization of Exosomes}

The increasing interest of the scientific community in using exosomes as drug nanovehicles has generated a growing need for sensitive methods capable of quantifying and characterizing these nanosized cell- secreted vesicles. Recent SPR reports in the field of exosome's investigation are based on the immobilization of specific antibodies against exosomal proteins onto the sensor surface and the measuring of SPR response as exosomes in solution are injected into the setup (Table 1). A thorough review of the use of SPR as a method for sensitive detection and molecular characterization of exosomes can be found in the literature (Rojalin et al., 2019).

\section{CONCLUSIONS}

SPR technology has emerged as an interesting strategy for studying different aspects of LNPs intended to deliver bioactive molecules, from the physicochemical characterization and quantification of lipid- based drug carriers to the study of the interaction of nanovehicles with the biological entities that they will encounter in therapeutic applications.

Although SPR technique is a well-established tool for studying molecular interactions, the experiment's reliability is based on the adequate immobilization of one of the interacting partners on the sensor surface and in the absence of interferences that could affect the resulting signals. Concerning LNPs, chemical constraints that may appear in the sensor surface preparation can be easily overcome as lipid based nanovehicles can be directly immobilized onto commercial lipid- capture chips by hydrophobic attachment.

\section{REFERENCES}

Akita, H., Nakatani, T., Kuroki, K., Maenaka, K., Tange, K., Nakai, Y., et al. (2015). Effect of hydrophobic scaffold on the cellular uptake and gene transfection activities of DNA-encapsulating liposomal nanoparticles via intracerebroventricular administration. Int. J. Pharm 490, 142-145. doi: 10.1016/j.ijpharm.2015.05.043

Al-Ahmady, Z. S., Chaloin, O., and Kostarelos, K. (2014). Monoclonal antibodytargeted, temperature-sensitive liposomes: In vivo tumor chemotherapeutics in combination with mild hyperthermia. J. Controll. Release 196, 332-343. doi: 10.1016/j.jconrel.2014.10.013

Albers, W. M., and Vikholm-Lundin, I. M. (2011). "Surface plasmon resonance on nanoscale organic films," in Nano-Bio-Sensing, ed S. Carrara (New York, NY: Springer), $4-10$

Allen, T. M., and Cullis, P. R. (2013). Liposomal drug delivery systems: from concept to clinical applications. Adv. Drug Deliv. Rev. 65, 36-48. doi: 10.1016/j.addr.2012.09.037

Bozzuto, G., and Molinari, A. (2015). Liposomes as nanomedical devices. Int. J. Nanomedicine 10, 975-999. doi: 10.2147/IJN.S68861

Bueloni, B., Sanna, D., Garribba, E., Castro, G. R., León, I. E., and Islan, G. A. (2020). Design of nalidixic acid-vanadium complex loaded into chitosan hybrid nanoparticles as smart strategy to inhibit bacterial growth and quorum sensing. Int. J. Biol. Macromol. 161, 1568-1580. doi: 10.1016/j.ijbiomac.2020.07.304

Bunker, A., Magarkar, A., and Viitala, T. (2016). Rational design of liposomal drug delivery systems, a review: combined experimental and computational studies
Regardless of the numerous reports presented in this review, SPR still remains as an underexploited technique in the field of LNP development and analysis. Measurement's simplicity and quickness should position SPR as a high-throughput technique for LNPs' characterization, providing preliminary information about biomolecular interactions that LNPs experiment in therapeutic applications and allowing to tune formulations before in vivo experiments. Finally, given the universal SPR detection principle, assays can be straight forward adapted to new drug carriers, a trend that with the incorporation of VLPs, exosomes and hybrid systems is in continuous growth.

\section{AUTHOR CONTRIBUTIONS}

CYC, MADM, JSC, EAR, and MEV wrote and revised the manuscript and approved it for publication. All authors contributed to the article and approved the submitted version.

\section{FUNDING}

This work was supported by Consejo Nacional de Investigaciones Científicas y Técnicas (CONICET) (PIP 0671 and PUE 22920170100100CO), Universidad Nacional de La Plata (PID 11/X861) and Agencia Nacional de Promoción Científica y Tecnológica- Ministerio de Ciencia, Tecnología e Innovación Productiva (PICT 2016-0679 and PICT 2018-02466).

\section{ACKNOWLEDGMENTS}

JSC was postdoctoral fellow of CONICET. CYC, MADM, and EAR were members of the research career of CONICET. MEV was member of the research career of CIC PBA.

of lipid membranes, liposomes and their PEGylation. Biochim. Biophys. Acta 1858, 2334-2352. doi: 10.1016/j.bbamem.2016.02.025

Cai, D., Gao, W., He, B., Dai, W., Zhang, H., Wang, X., et al. (2014). Hydrophobic penetrating peptide PFVYLI-modified stealth liposomes for doxorubicin delivery in breast cancer therapy. Biomaterials 35, 2283-2294. doi: 10.1016/j.biomaterials.2013.11.088

Canovi, M., Lucchetti, J., Stravalaci, M., Re, F., Moscatelli, D., Bigini, P., et al. (2012). Applications of surface plasmon resonance (SPR) for the characterization of nanoparticles developed for biomedical purposes. Sensors 12, 16420-16432. doi: 10.3390/s121216420

Choi, Y. H., and Han, H.-K. (2018). Nanomedicines: current status and future perspectives in aspect of drug delivery and pharmacokinetics. J. Pharm. Invest. 48, 43-60. doi: 10.1007/s40005-017-0370-4

Crielaard, B. J., Yousefi, A., Schillemans, J. P., Vermehren, C., Buyens, K., Braeckmans, K., et al. (2011). An in vitro assay based on surface plasmon resonance to predict the in vivo circulation kinetics of liposomes. J. Controll. Release 156, 307-314. doi: 10.1016/j.jconrel.2011.07.023

Del Vecchio, K., and Stahelin, R. V. (2016). "Using surface plasmon resonance to quantitatively assess lipid-protein interactions," in Methods in Molecular Biology, ed J. M. Walker (New York, NY: Humana Press), 141-153.

Desfrançois, C., Auzély, R., and Texier, I. (2018). Lipid nanoparticles and their hydrogel composites for drug delivery: a review. Pharmaceuticals 11:118. doi: 10.3390/ph11040118

Di Ianni, M. E., Islan, G. A., Chain, C. Y., Castro, G. R., Talevi, A., and Vela, M. E. (2017). Interaction of solid lipid nanoparticles and specific proteins 
of the corona studied by surface plasmon resonance. J. Nanomater. 2017:11. doi: 10.1155/2017/6509184

Ding, Q., Si, X., Liu, D., Peng, J., Tang, H., Sun, W., et al. (2015). Targeting and liposomal drug delivery to CD40L expressing $\mathrm{T}$ cells for treatment of autoimmune diseases. J. Controll. Release 207, 86-92. doi: 10.1016/j.jconrel.2015.03.035

Duff, M. R. Jr., Grubbs, J., and Howell, E. E. (2011). Isothermal titration calorimetry for measuring macromolecule-ligand affinity. J. Vis. Exp. 55:2796. doi: 10.3791/2796

Efremova, N. V., Bondurant, B., O'brien, D. F., and Leckband, D. E. (2000). Measurements of interbilayer forces and protein adsorption on uncharged lipid bilayers displaying poly(ethylene glycol) chains. Biochemistry 39, 3441-3451. doi: 10.1021/bi992095r

Etzerodt, A., Maniecki, M. B., Graversen, J. H., Moller, H. J., Torchilin, V. P., and Moestrup, S. K. (2012). Efficient intracellular drug-targeting of macrophages using stealth liposomes directed to the hemoglobin scavenger receptor CD163. J. Controll. Release 160, 72-80. doi: 10.1016/j.jconrel.2012.01.034

Fontana, E. (2006). Thickness optimization of metal films for the development of surface-plasmon-based sensors for nonabsorbing media. Appl. Opt. 45, 7632-7642. doi: 10.1364/AO.45.007632

Gao, L.-Y., Liu, X.-Y., Chen, C.-J., Wang, J.-C., Feng, Q., Yu, M.Z., et al. (2014). Core-Shell type lipid/rPAA-Chol polymer hybrid nanoparticles for in vivo siRNA delivery. Biomaterials 35, 2066-2078. doi: 10.1016/j.biomaterials.2013.11.046

Gedig, E. T. (2017). "Chapter 6 surface chemistry in SPR technology," in Handbook of Surface Plasmon Resonance, ed R. B. M. Schasfoort (London: The Royal Society of Chemistry), 171-254.

Gobbi, M., Re, F., Canovi, M., Beeg, M., Gregori, M., Sesana, S., et al. (2010). Lipid-based nanoparticles with high binding affinity for amyloid- $\beta 1-42$ peptide. Biomaterials 31, 6519-6529. doi: 10.1016/j.biomaterials.2010.04.044

Gregori, M., Taylor, M., Salvati, E., Re, F., Mancini, S., Balducci, C., et al. (2017). Retro-inverso peptide inhibitor nanoparticles as potent inhibitors of aggregation of the Alzheimer's A $\beta$ peptide. Nanomedicine 13, 723-732. doi: $10.1016 /$ j.nano.2016.10.006

Guo, Z., He, B., Jin, H., Zhang, H., Dai, W., Zhang, L., et al. (2014). Targeting efficiency of RGD-modified nanocarriers with different ligand intervals in response to integrin $\alpha \mathrm{v} \beta 3$ clustering. Biomaterials 35, 6106-6117. doi: 10.1016/j.biomaterials.2014.04.031

György, B., Hung, M. E., Breakefield, X. O., and Leonard, J. N. (2015). Therapeutic applications of extracellular vesicles: clinical promise and open questions. Annu. Rev. Pharmacol. Toxicol. 55, 439-464. doi: 10.1146/annurev-pharmtox-010814-124630

Ha, D., Yang, N., and Nadithe, V. (2016). Exosomes as therapeutic drug carriers and delivery vehicles across biological membranes: current perspectives and future challenges. Acta Pharm. Sin. B 6, 287-296. doi: 10.1016/j.apsb.2016. 02.001

Hermanson, G. T. (2013). "Chapter 3 - the reactions of bioconjugation," in Bioconjugate Techniques, 3rd Edn, ed G. T. Hermanson (Boston, MA: Academic Press), 229-258.

Hodnik, V., and Anderluh, G. (2013). Surface plasmon resonance for measuring interactions of proteins with lipid membranes. Methods Mol. Biol. 974, 23-36. doi: 10.1007/978-1-62703-275-9_2

Huang, Z. R., Tipparaju, S. K., Kirpotin, D. B., Pien, C., Kornaga, T., Noble, C. O., et al. (2019). Formulation optimization of an ephrin A2 targeted immunoliposome encapsulating reversibly modified taxane prodrugs. J. Controll. Release 310, 47-57. doi: 10.1016/j.jconrel.2019.08.006

Im, H., Yang, K., Lee, H., and Castro, C. M. (2017). Characterization of extracellular vesicles by surface plasmon resonance. Methods Mol. Biol. 1660, 133-141. doi: 10.1007/978-1-4939-7253-1_11

Jedynak, M., Worch, R., Podsiadła-Białoskórska, M., Chroboczek, J., and Szołajska, E. (2018). Cholesterol and phosphatidylserine are engaged in adenoviral dodecahedron endocytosis. Biochim. Biophys. Acta Biomembr. 1860, 2215-2223. doi: 10.1016/j.bbamem.2018.09.002

Jerabek-Willemsen, M., André, T., Wanner, R., Roth, H. M., Duhr, S., Baaske, P., et al. (2014). MicroScale thermophoresis: interaction analysis and beyond. J. Mol. Struct. 1077, 101-113. doi: 10.1016/j.molstruc.2014.03.009

Kari, O. K., Rojalin, T., Salmaso, S., Barattin, M., Jarva, H., Meri, S., et al. (2017). Multi-parametric surface plasmon resonance platform for studying liposome-serum interactions and protein corona formation. Drug Deliv. Transl. Res. 7, 228-240. doi: 10.1007/s13346-016-0320-0

Laukkanen, M. L., Alfthan, K., and Keinänen, K. (1994). Functional immunoliposomes harboring a biosynthetically lipid-tagged single-chain antibody. Biochemistry 33, 11664-11670. doi: 10.1021/bi00204a031

Li, C., Wang, J., Wang, Y., Gao, H., Wei, G., Huang, Y., et al. (2019). Recent progress in drug delivery. Acta Pharm. Sin. B 9, 1145-1162. doi: $10.1016 /$ j.apsb.2019.08.003

Maier, S. A. (2007). "Electromagnetics of metals," in Plasmonics: Fundamentals and Applications, ed S. A. Maier (New York, NY: Springer), 5-19.

Malmsten, M. (1999). Studies of serum protein adsorption at phospholipid surfaces in relation to intravenous drug delivery. Colloids Surf. A Physicochem. Eng. Aspects 159, 77-87. doi: 10.1016/S0927-7757(99)00164-8

Mehnert, W., and Mäder, K. (2012). Solid lipid nanoparticles: production, characterization and applications. Adv. Drug Deliv. Rev. 64, 83-101. doi: 10.1016/j.addr.2012.09.021

Meierhofer, T., van den Elsen, J. M. H., Cameron, P. J., Muñoz-Berbel, X., and Jenkins, A. T. A. (2010). The interaction of serum albumin with cholesterol containing lipid vesicles. J. Fluoresc. 20, 371-376. doi: 10.1007/s10895-009-0522-7

Mizrahy, S., Raz, S. R., Hasgaard, M., Liu, H., Soffer-Tsur, N., Cohen, K., et al. (2011). Hyaluronan-coated nanoparticles: the influence of the molecular weight on CD44-hyaluronan interactions and on the immune response. J. Controll. Release 156, 231-238. doi: 10.1016/j.jconrel.2011.06.031

Mourtas, S., Canovi, M., Zona, C., Aurilia, D., Niarakis, A., La Ferla, B., et al. (2011). Curcumin-decorated nanoliposomes with very high affinity for amyloid- $\beta 1-42$ peptide. Biomaterials 32, 1635-1645. doi: $10.1016 /$ j.biomaterials.2010.10.027

Naseri, N., Valizadeh, H., and Zakeri-Milani, P. (2015). Solid lipid nanoparticles and nanostructured lipid carriers: structure, preparation and application. $A d v$. Pharm. Bull. 5, 305-313. doi: 10.15171/apb.2015.043

Nielsen, U. B., Kirpotin, D. B., Pickering, E. M., Hong, K., Park, J. W., Refaat Shalaby, M., et al. (2002). Therapeutic efficacy of anti-ErbB2 immunoliposomes targeted by a phage antibody selected for cellular endocytosis. Biochim. Biophys. Acta Mol. Cell Res. 1591, 109-118. doi: 10.1016/S0167-4889(02)00256-2

Oner, E., Kotmakci, M., and Kantarci, A. G. (2020). A promising approach to develop nanostructured lipid carriers from solid lipid nanoparticles: preparation, characterization, cytotoxicity and nucleic acid binding ability. Pharm. Dev. Technol. 25, 936-948. doi: 10.1080/10837450.2020.1759630

Pan, H., Ivashyna, O., Sinha, B., Lanza, G. M., Ratner, L., Schlesinger, P. H., et al. (2011). Post-formulation peptide drug loading of nanostructures for metered control of NF- $\mathrm{BB}$ signaling. Biomaterials 32, 231-238. doi: $10.1016 /$ j.biomaterials.2010.08.080

Pattni, B. S., Chupin, V. V., and Torchilin, V. P. (2015). New developments in liposomal drug delivery. Chem. Rev. 115, 10938-10966. doi: 10.1021/acs.chemrev.5b00046

Pearson, R. M., Juettner, V. V., and Hong, S. (2014). Biomolecular corona on nanoparticles: a survey of recent literature and its implications in targeted drug delivery. Front. Chem. 2:108. doi: 10.3389/fchem.2014.00108

Puri, A., Loomis, K., Smith, B., Lee, J.-H., Yavlovich, A., Heldman, E., et al. (2009). Lipid-based nanoparticles as pharmaceutical drug carriers: from concepts to clinic. Crit. Rev. Ther. Drug Carrier Syst. 26, 523-580. doi: 10.1615/CritRevTherDrugCarrierSyst.v26.i6.10

Rafique, A., Etzerodt, A., Graversen, J. H., Moestrup, S. K., Dagnæs-Hansen, F., and Møller, H. J. (2019). Targeted lipid nanoparticle delivery of calcitriol to human monocyte-derived macrophages in vitro and in vivo: investigation of the anti-inflammatory effects of calcitriol. Int. J. Nanomedicine 14, 2829-2846. doi: $10.2147 / \mathrm{IJN} . S 192113$

Rauscher, A., Frindel, M., Maurel, C., Maillasson, M., Le Saëc, P., Rajerison, H., et al. (2014). Influence of pegylation and hapten location at the surface of radiolabelled liposomes on tumour immunotargeting using bispecific antibody. Nucl. Med. Bio. 41, e66-e74. doi: 10.1016/j.nucmedbio.2013.12.012

Rodenak-Kladniew, B., Scioli Montoto, S., Sbaraglini, M. L., Di Ianni, M., Ruiz, M. E., Talevi, A., et al. (2019). Hybrid Ofloxacin/eugenol co-loaded solid lipid nanoparticles with enhanced and targetable antimicrobial properties. Int. J. Pharm. 569:118575. doi: 10.1016/j.ijpharm.2019.118575

Rohovie, M. J., Nagasawa, M., and Swartz, J. R. (2017). Virus-like particles: next-generation nanoparticles for targeted therapeutic 
delivery. Bioeng. Transl. Med. 2, 43-57. doi: 10.1002/btm2. 10049

Rojalin, T., Phong, B., Koster, H. J., and Carney, R. P. (2019). Nanoplasmonic approaches for sensitive detection and molecular characterization of extracellular vesicles. Front. Chem. 7:729. doi: 10.3389/fchem.2019.00279

Rupert, D. L. M., Lässer, C., Eldh, M., Block, S., Zhdanov, V. P., Lotvall, J. O., et al. (2014). Determination of exosome concentration in solution using surface plasmon resonance spectroscopy. Anal. Chem. 86, 5929-5936. doi: $10.1021 /$ ac500931f

Rupert, D. L. M., Shelke, G. V., Emilsson, G., Claudio, V., Block, S., Lässer, C., et al. (2016). Dual-wavelength surface plasmon resonance for determining the size and concentration of sub-populations of extracellular vesicles. Anal. Chem. 88, 9980-9988. doi: 10.1021/acs.analchem.6b01860

Sandoval-Altamirano, C., Sanchez, S. A., Ferreyra, N. F., and Gunther, G. (2017). Understanding the interaction of concanavalin a with mannosyl glycoliposomes: a surface plasmon resonance and fluorescence study. Colloids Surf. B Biointerfaces 158, 539-546. doi: 10.1016/j.colsurfb.2017.07.026

Schasfoort, R. B. M. (2017). "Chapter 1: introduction to surface plasmon resonance," in Handbook of Surface Plasmon Resonance, ed R. B. M. Schasfoort (London: The Royal Society of Chemistry), 1-26. doi: 10.1039/9781788010283-00001

Selvamuthukumar, S., and Velmurugan, R. (2012). Nanostructured lipid carriers: a potential drug carrier for cancer chemotherapy. Lipids Health Dis. 11:59. doi: 10.1186/1476-511X-11-159

Seong, H., Choi, W. M., Kim, J. C., Thompson, D. H., and Park, K. (2003). Preparation of liposomes with glucose binding sites: liposomes containing di-branched amino acid derivatives. Biomaterials 24, 4487-4493. doi: 10.1016/S0142-9612(03)00352-1

Shi, K., Li, J., Cao, Z., Yang, P., Qiu, Y., Yang, B., et al. (2015a). A pH-responsive cell-penetrating peptide-modified liposomes with active recognizing of integrin $\alpha \mathrm{v} \beta 3$ for the treatment of melanoma. J. Controll. Release 217, 138-150. doi: 10.1016/j.jconrel.2015.09.009

Shi, K., Long, Y., Xu, C., Wang, Y., Qiu, Y., Yu, Q., et al. (2015b). Liposomes combined an integrin $\alpha \mathrm{v} \beta 3$-specific vector with ph-responsible cell-penetrating property for highly effective antiglioma therapy through the blood-brain barrier. ACS Appl. Mater. Interfaces 7, 21442-21454. doi: 10.1021/acsami.5b06429

Shibata, H., Saito, H., Yomota, C., Kawanishi, T., and Okuda, H. (2012). Alterations in the detergent-induced membrane permeability and solubilization of saturated phosphatidylcholine/cholesterol liposomes: effects of poly(ethylene glycol)-conjugated lipid. Chem. Pharm. Bull. 60, 1105-1111. doi: $10.1248 / \mathrm{cpb} . c 12-00153$

Shibata, H., Yoshida, H., Izutsu, K. I., Haishima, Y., Kawanishi, T., Okuda, H., et al. (2015). Interaction kinetics of serum proteins with liposomes and their effect on phospholipase-induced liposomal drug release. Int. J. Pharm. 495, 827-839. doi: 10.1016/j.ijpharm.2015.09.053

Skyttner, C., Selegård, R., Larsson, J., Aronsson, C., Enander, K., and Aili, D. (2019). Sequence and length optimization of membrane active coiled coils for triggered liposome release. Biochim. Biophys. Acta Biomember. 1861, 449-456. doi: 10.1016/j.bbamem.2018.11.005

Soman, N. R., Baldwin, S. L., Hu, G., Marsh, J. N., Lanza, G. M., Heuser, J. E., et al. (2009). Molecularly targeted nanocarriers deliver the cytolytic peptide melittin specifically to tumor cells in mice, reducing tumor growth. J. Clin. Invest. 119, 2830-2842. doi: $10.1172 / J C I 38842$

Soman, N. R., Lanza, G. M., Heuser, J. M., Schlesinger, P. H., and Wickline, S. A. (2008). Synthesis and characterization of stable fluorocarbon nanostructures as drug delivery vehicles for cytolytic peptides. Nano Lett. 8, 1131-1136. doi: $10.1021 / \mathrm{nl} 073290 \mathrm{r}$

Sugano, M., Morisaki, H., Negishi, Y., Endo-Takahashi, Y., Kuwata, H., Miyazaki, T., et al. (2016). Potential effect of cationic liposomes on interactions with oral bacterial cells and biofilms. J. Liposome Res. 26, 156-162. doi: 10.3109/08982104.2015.1063648

Tamiaki, H., Azefu, Y., Shibata, R., Sato, R., and Toma, K. (2006). Oligomethylene spacer length dependent interaction of synthetic galactolipids incorporated in phospholipid layers with ricin. Colloids Surf B Biointerfaces 53, 87-93. doi: 10.1016/j.colsurfb.2006.08.001

Terada, T., Mizobata, M., Kawakami, S., Yamashita, F., and Hashida, M. (2007). Optimization of tumor-selective targeting by basic fibroblast growth factor-binding peptide grafted PEGylated liposomes. J. Control. Release 119, 262-270. doi: 10.1016/j.jconrel.2007.01.018

Tonda-Turo, C., Carmagnola, I., and Ciardelli, G. (2018). Quartz crystal microbalance with dissipation monitoring: a powerful method to predict the in vivo behavior of bioengineered surfaces. Front. Bioeng. Biotech. 6:158. doi: 10.3389/fbioe.2018.00158

Vericat, C., Vela, M. E., Benitez, G., Carro, P., and Salvarezza, R. C. (2010). Selfassembled monolayers of thiols and dithiols on gold: new challenges for a well-known system. Chem. Soc. Rev. 39, 1805-1834. doi: 10.1039/b907301a

Viitala, T., Liang, H., Gupta, M., Zwinger, T., Yliperttula, M., and Bunker, A. (2012). Fluid dynamics modeling for synchronizing surface plasmon resonance and quartz crystal microbalance as tools for biomolecular and targeted drug delivery studies. J. Colloid Interface Sci. 378, 251-259. doi: 10.1016/j.jcis.2012.04.012

Wadajkar, A. S., Dancy, J. G., Carney, C. P., Hampton, B. S., Ames, H. M., Winkles, J. A., et al. (2019). Leveraging surface plasmon resonance to dissect the interfacial properties of nanoparticles: implications for tissue binding and tumor penetration. Nanomedicine 20:102024. doi: 10.1016/j.nano.2019.102024

Wang, X., Chen, X., Yang, X., He, B., Dai, W., Wang, X., et al. (2014). A mechanism study on the tamoxifen mediated cellular internalization of liposomes. J. Chin. Pharm. Sci. 23, 595-600. doi: 10.5246/jcps.2014.09.076

Weeramange, C. J., Fairlamb, M. S., Singh, D., Fenton, A. W., and Swint-Kruse, L. (2020). The strengths and limitations of using biolayer interferometry to monitor equilibrium titrations of biomolecules. Protein Sci. 29, 1004-1020. doi: $10.1002 /$ pro.3827

Wiklander, O. P. B., Brennan, M. Á., Lötvall, J., Breakefield, X. O., and Andaloussi, S. E. L. (2019). Advances in therapeutic applications of extracellular vesicles. Sci. Transl. Med. 11:eaav8521. doi: 10.1126/scitranslmed.aav8521

Xiang, Y., Kiseleva, R., Reukov, V., Mulligan, J., Atkinson, C., Schlosser, R., et al. (2015). Relationship between targeting efficacy of liposomes and the dosage of targeting antibody using surface plasmon resonance. Langmuir 31, 12177-12186. doi: 10.1021/acs.langmuir.5b01386

Yan, L., Zhao, F., Wang, J., Zu, Y., Gu, Z., and Zhao, Y. (2019). A safe-bydesign strategy towards safer nanomaterials in nanomedicines. Adv. Mater. 31:e1805391. doi: 10.1002/adma.201805391

Yatuv, R., Carmel-Goren, L., Dayan, I., Robinson, M., and Baru, M. (2009). Binding of proteins to PEGylated liposomes and improvement of G-CSF efficacy in mobilization of hematopoietic stem cells. J. Controll. Release 135, 44-50. doi: 10.1016/j.jconrel.2008.12.004

Yeh, Y.-C., Huang, T.-H., Yang, S.-C., Chen, C.-C., and Fang, J.-Y. (2020). Nanobased drug delivery or targeting to eradicate bacteria for infection mitigation: a review of recent advances. Front. Chem. 8:286. doi: 10.3389/fchem.2020. 00286

Zdanowicz, M., and Chroboczek, J. (2016). Virus-like particles as drug delivery vectors. Acta Biochim. Pol. 63, 469-473. doi: 10.18388/abp.2016 1275

Zhao, F., Cheng, X., Liu, G., and Zhang, G. (2010). Interaction of hydrophobically end-capped polyethylene glycol with phospholipid vesicles: The hydrocarbon end-chain length dependence. J. Phys. Chem. B 114, 1271-1276. doi: $10.1021 /$ jp910024n

Zhao, Z., Ukidve, A., Krishnan, V., and Mitragotri, S. (2019). Effect of physicochemical and surface properties on in vivo fate of drug nanocarriers. Adv. Drug Deliv. Rev. 143, 3-21. doi: 10.1016/j.addr.2019.01.002

Zylberberg, C., and Matosevic, S. (2016). Pharmaceutical liposomal drug delivery: a review of new delivery systems and a look at the regulatory landscape. Drug Deliv. 23, 3319-3329. doi: 10.1080/10717544.2016. 1177136

Conflict of Interest: The authors declare that the research was conducted in the absence of any commercial or financial relationships that could be construed as a potential conflict of interest.

Copyright (๑ 2021 Chain, Daza Millone, Cisneros, Ramirez and Vela. This is an open-access article distributed under the terms of the Creative Commons Attribution License (CC BY). The use, distribution or reproduction in other forums is permitted, provided the original author(s) and the copyright owner(s) are credited and that the original publication in this journal is cited, in accordance with accepted academic practice. No use, distribution or reproduction is permitted which does not comply with these terms. 